\title{
The autumn 1919 Torremendo (Jacarilla) earthquake series (SE Spain)
}

\author{
Josep Batlló ${ }^{1, \star}$, José Manuel Martínez-Solares ${ }^{2,5}$, Ramon Macià ${ }^{3}$, Daniel Stich ${ }^{4,6}$, \\ José Morales ${ }^{4,6}$, Lurdes Garrido ${ }^{5}$
}

\author{
${ }^{1}$ Instituto Dom Luiz, Univers. de Lisboa, Portugal; now at Institut Cartogràfic i Geologic de Catalunya, Barcelona, Spain \\ ${ }^{2}$ Instituto Geográfico Nacional, Ministerio de Fomento, Madrid, Spain \\ ${ }^{3}$ Universitat Politècnica de Catalunya, Dept. Matemática Aplicada II, Barcelona, Spain \\ ${ }^{4}$ Instituto Andaluz de Geofisica, Universidad de Granada, Granada, Spain \\ ${ }^{5}$ Universidad Complutense de Madrid, Dept. Geofisica y Meteorologia, Madrid, Spain \\ ${ }^{6}$ Universidad de Granada, Dept. De Física Teórica y del Cosmos, Granada, Spain
}

\section{Article history}

Received October 23, 2014; accepted March 25, 2015.

Subject classification:

Jacarilla earthquake, Moment magnitude, Environmental effects, Aftershock series, Macroseismicity.

\begin{abstract}
On 10th September 1919 several slightly damaging earthquakes struck the towns of Torremendo, Jacarilla (near Alicante, SE-Spain) and others nearby. Available magnitude estimations for the largest two events of the series are $M=5$ approx. They were earthquakes of moderate size and they occurred in a region where similar magnitude earthquakes, thoroughly studied, occurred recently (1999 Mula; 2002 Bullas; 2005 La Paca; 2011 Lorca). This makes these events of interest for a better definition of the regional seismicity. We study their sources from the analysis of the available contemporary seismograms and related documents. A total of 23 seismograms from 9 seismic stations have been collected and digitized. These seismograms contain records for the two main events and several aftershocks of the earthquake series. Finally 44 files, corresponding to 44 recorded single component records from the different events have been processed. The events have been relocated and their magnitudes recalculated. Also, original macroseismic information for these events was recovered. A macroseismic evaluation of the series has been performed. Intensity data points have been recalculated and macroseismic location and magnitude obtained. We conclude that these are the largest earthquakes occurred in the region since the beginning of instrumental recording, with $\mathrm{Mw}=5.5$ for the largest shock, and that the available data could be compatible with a thrust mechanism related to blind faults in the Bajo Segura region.
\end{abstract}

\section{Introduction}

The seismicity of the SE region of the Iberian Peninsula is tied to the recent evolution of the Betics Cordillera and thus, to the collision of the Euroasiatic and Nubian plates (see Stich et al. [2010], and references therein). The regional geology is complex and several differentiated geological units can be defined in this area. The Eastern Betic Cordillera includes the Eastern Betic Shear Zone (EBSZ) and the Crevillente Fault. The Bajo Segura Basin is located in the NE end of the Eastern Betic Shear Zone [Silva et al. 1993] or the TransAlboran Shear Zone [De Larouzière et al. 1988]. It is bordered by the Bajo Segura fault (south) and the Crevillente fault (north) (see regional setting or geodynamic setting in Alfaro et al. [2002, 2012], Bousquet [1979], Silva et al. [1993], among others).

The region is characterized by a moderate seismicity; but damaging earthquakes, causing injuries and even deaths, as the recent Lorca earthquakes (Mw 5.1) on 11 May 2011 [see Morales et al. 2014, Rueda et al. 2014] are not excluded. Such earthquakes are, in fact, quite common. Among them, those occurred near Mula (2 February 1999, Mw 4.8), Bullas (6 August 2002, Mw 5.0) [Buforn et al. 2005] and Aledo (29 January 2005, Mw 4.8) [Benito et al. 2007, Gaspar-Escribano and Benito 2007] are the most recent events affecting the region and object of several studies. But we know of other similar events in the 20th century: Lorquí (21 March and 3 April 1911) [Buforn et al. 2005], Jacarilla (10 September 1919) [Sánchez Navarro-Neumann 1919a, 1919b], Caravaca (23 June 1948) [Rey Pastor 1949] or also another smaller event occurred near Lorca on 6 June 1977 [Mezcua et al. 1984]. The historical earthquake references for this region go back to one thousand years. The oldest known event occurred near Orihuela on 1048 [Bretón and Espinar 1996], and that 


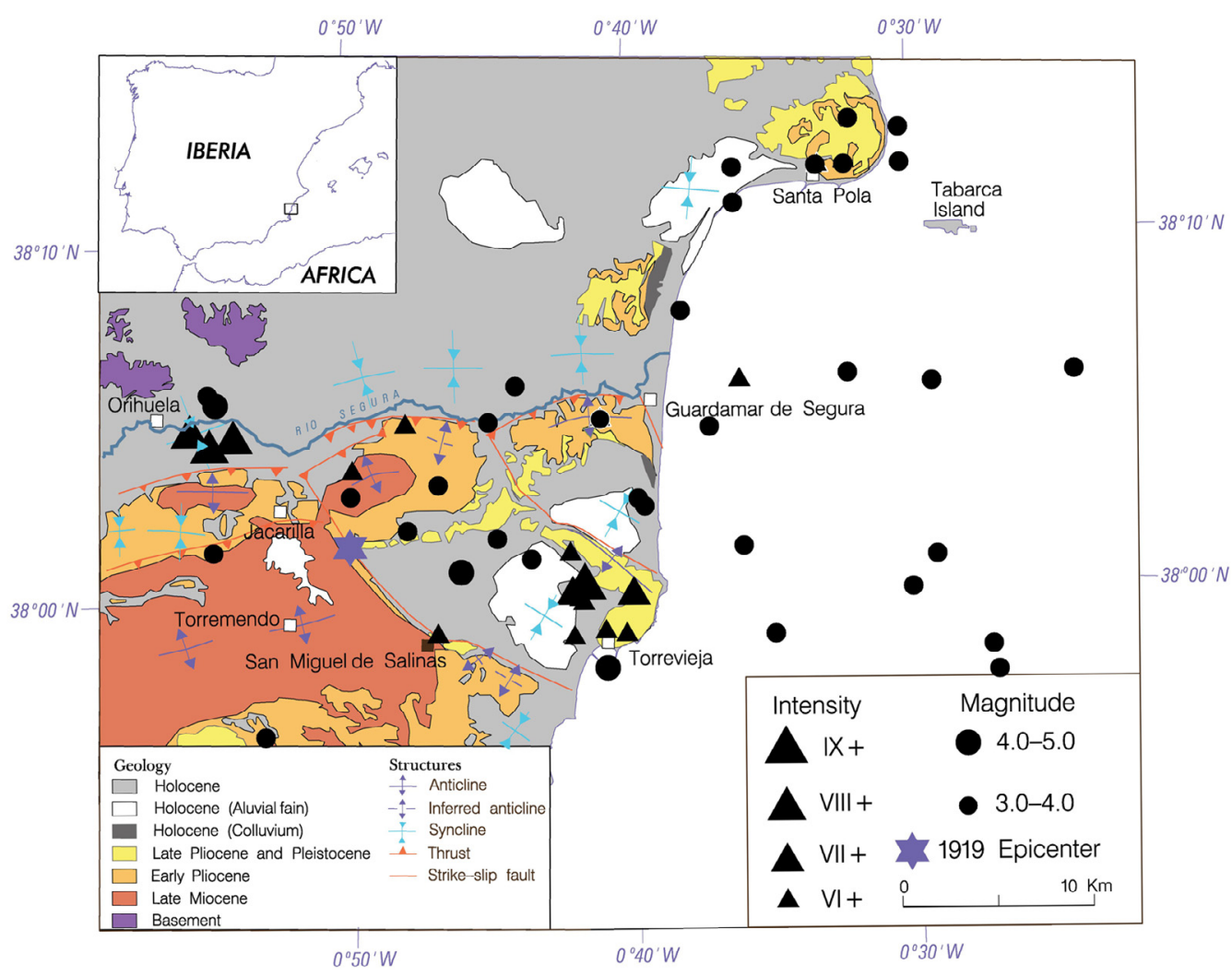

Figure 1. The lower Segura river valley geological sketch and seismicity. The main units and structural features are shown. Recent Holocene terrains cover a large amount of the region, but outcrops of Pliocene terrain are present mainly on the SW part of the region. The main observed surface strike-slip faults follow an almost NW-SE trend. Instead, the thrust faults show a WSW-ENE trend. Epicenters of earthquakes with intensity equal or larger than VI (triangles) or magnitude equal or larger than 3.0 (dots), as consigned in the IGN online catalogue are shown.

occurred near Torrevieja on 21 March 1829 [Larramendi 1829] was the most destructive one. There exist also indirect evidences related to paleoliquefaction [Alfaro et al. 1999, 2001].

From its macroseismic effects, the 1919 earthquake is the largest one of those occurred in the region since instrumental records are available and previous to the WWSSN deployment (1962 onwards). Many aftershocks are documented and several studies on this earthquake were published shortly after its occurrence [Sánchez Navarro-Neumann 1919a, Sánchez Navarro-Neumann 1919b, Kindelán and Gorostizaga 1920, Inglada 1926, Inglada 1927], but it has never been reviewed in recent times. Most likely, its source can be associated to the activity of the Bajo Segura blind fault, with a well documented activity from the geological record [Taboada et al. 1993, Alfaro et al. 2002, Alfaro et al. 2012]. The large historical events occurred in 1048 and 1829 have been associated to its activity. Instead, the 1919 events are the largest earthquakes recorded there in the 20th century. For these reasons, and to gain more insight in the patterns of regional seismicity, we decided to study again these events from their instrumental records. Fortuitously, on looking for these records, we discovered a complete contemporary report with detailed macroseismic information, with new information about the main event and the aftershocks. Thus, we decided to complete our analysis with the study of the macroseismic field of these earthquakes.

\section{The 1919 Jacarilla/Torremendo earthquake series}

From the contemporary reports and news we know that this series of earthquakes started on 10 September 1919. Two main shocks occurred within $16 \mathrm{~min}$ (10:40 and 10:56 GMT) and were followed by many aftershocks (some reports say more than 12 were felt on the first day) lasting for several weeks. This "double" main shock pattern (two main events of similar size occurring with an interval of hours to a few days) is not unusual on the earthquakes of that zone [Martínez-Solares et al. 2012]. The 2011 Lorca earthquake showed this pattern as well as the 1911 Lorqui event. Also, the large number of felt aftershocks related to the relatively small size of the main events is quite common in the region. In fact, the available catalogues for our studied events [Galbis 1932, Munuera 1963, Mezcua and Martínez-Solares 1983] do not agree in the number, date and time of aftershocks.

Short after the occurrence of the earthquakes, several studies and specific information were published. «Revista Ibérica», a contemporary Spanish Journal for Science popularization, published detailed information 


\begin{tabular}{|c|c|c|c|c|c|c|c|}
\hline Station & Instrument & Components & Magnification & $\begin{array}{c}\text { Free period } \\
(\mathrm{s})\end{array}$ & Damping & $\begin{array}{l}\text { Record speed } \\
(\mathrm{mm} / \mathrm{min})\end{array}$ & $\begin{array}{c}\Delta^{\circ} \\
(\mathrm{km})\end{array}$ \\
\hline \multirow{3}{*}{ ALI } & \multirow{3}{*}{$\begin{array}{l}\text { Vicentini } \\
\text { (1) }\end{array}$} & E-W & 90 & 2.5 & - & 10.0 & 43 \\
\hline & & N-S & 84 & 2.5 & - & 10.0 & \\
\hline & & $Z$ & 113 & 0.9 & - & 10.0 & \\
\hline \multirow{2}{*}{ ALI } & \multirow{2}{*}{$\begin{array}{c}\text { Bosch-Omori } \\
\text { (4) }\end{array}$} & E-W & 13 & 18.0 & 0.25 & 14.8 & 43 \\
\hline & & $\mathrm{N}-\mathrm{S}$ & 13 & 18.0 & 0.25 & 15.0 & \\
\hline \multirow{3}{*}{ ALM } & \multirow{3}{*}{$\begin{array}{l}\text { Vicentini } \\
\text { (1) }\end{array}$} & E-W & 90 & 2.4 & - & 10.0 & 198 \\
\hline & & N-S & 90 & 2.4 & - & 10.0 & \\
\hline & & $Z$ & 85 & 0.9 & - & 10.0 & \\
\hline \multirow{2}{*}{ CRT } & \multirow{2}{*}{$\begin{array}{l}\text { Bifilar } \\
\text { (2) }\end{array}$} & $E-W$ & 60 & 10.0 & 0.40 & 10.5 & 263 \\
\hline & & N-S & 60 & 10.0 & 0.40 & 10.5 & \\
\hline \multirow{2}{*}{ TOL } & \multirow{2}{*}{$\begin{array}{c}\text { Bosch-Omori } \\
\text { (2) }\end{array}$} & E-W & 15 & 12.0 & 0.30 & 15.0 & 343 \\
\hline & & N-S & 15 & 12.0 & 0.30 & 14.7 & \\
\hline \multirow{2}{*}{ EBR } & \multirow{2}{*}{$\begin{array}{c}\text { Mainka-Ebro } \\
\text { (3) }\end{array}$} & E-W & 110 & 7.8 & 0.35 & 12.2 & 325 \\
\hline & & $\mathrm{N}-\mathrm{W}$ & 200 & 14.5 & 0.30 & 12.0 & \\
\hline \multirow{2}{*}{ FBR } & \multirow{2}{*}{$\begin{array}{c}\text { Mainka } \\
\text { (2) }\end{array}$} & E-W & 60 & 9.0 & 0.40 & 16.2 & 449 \\
\hline & & N-S & 50 & 9.0 & 0.40 & 16.2 & \\
\hline \multirow{2}{*}{ PAR } & \multirow{2}{*}{$\begin{array}{l}\text { Wiechert } \\
\text { (2) }\end{array}$} & E-W & 225 & 11.0 & 0.40 & 12.6 & 1222 \\
\hline & & N-S & 225 & 10.7 & 0.40 & 12.6 & \\
\hline PAR & Galitzin (1) & $Z$ & 1330 & 11.7 & Critical & 20.3 & 1222 \\
\hline \multirow{3}{*}{ STR } & \multirow{3}{*}{$\begin{array}{l}\text { Wiechert } \\
\text { (3) }\end{array}$} & E-W & 180 & 9.0 & 0.40 & 15.0 & 1358 \\
\hline & & N-W & 180 & 9.0 & 0.40 & 15.0 & \\
\hline & & Z & & & & & \\
\hline \multirow{2}{*}{ DBN } & \multirow{2}{*}{$\begin{array}{l}\text { Galitzin } \\
\text { (2) }\end{array}$} & E-W & 247 & 25.0 & Critical & 30.0 & 1628 \\
\hline & & N-S & 247 & 25.0 & Critical & 30.0 & \\
\hline
\end{tabular}

Table 1. List of collected seismograms with the main recording characteristics of the instruments. The numbers on brackets (column 2 ) show the number of original seismograms collected for each instrument. The last column list the distance from the station to the earthquake epicenter.

on aftershock times [Datos sísmicos 1919, 1920]. Sánchez Navarro-Neumann [1919a, 1919b] published both instrumental and macroseismic studies of these earthquakes. Kindelán and Gorostizaga [1920] published a macroseismic study. Inglada [1926, 1927] calculated the depth of the main shock from instrumental records. Finally, Rey Pastor [1943] described the occurrence of these earthquakes on the framework of the general geologic and seismotectonic setting of the region as understood at that time.

\section{Data collection}

\subsection{Instrumental data}

For our study from instrumental records we searched and collected seismograms, station bulletins and, even in the first moment wasn't our main objective, information about macroseismic effects for these earthquakes. Original bulletins were collected for different stations; also those existing only in manuscript form, as it is the case for TOL and EBR. Data published in the International Seismological Summary [ISS 1924] for these earthquakes are presented in a misleading way. In fact, ISS totally miss these earthquakes as analyzed in the earthquake location section. A total of 23 seismograms from 9 seismic stations have been collected and scanned. It is worth to note the case of CRT, where original seismograms were not preserved, but we get one component through a photographic contact preserved at the station and another was reproduced in Sánchez Navarro-Neumann [1919b]. Table 1 shows the collected seismograms and the assumed instrumental constants for their processing. Besides the two main shocks, $16 \mathrm{~min}$. apart, showing almost identical records, some aftershock records were also collected.

\subsection{Macroseismic data}

As already stated, on searching for seismograms and related documents, a manuscript report compiling the macroseismic effects of the main shock and assigned intensity values was found. The document authors were not consigned; but it is written on pur- 
BATLLÓ ET AL.

\begin{tabular}{|c|c|c|c|c|}
\hline & $\begin{array}{l}\text { Definitive } \\
\text { EMS98 }\end{array}$ & $\begin{array}{l}\text { Report } \\
\text { MCS }\end{array}$ & $\begin{array}{c}\text { Galbis }[1932] \\
\text { MCS }\end{array}$ & $\begin{array}{c}\text { Sánchez }[1919 a] \\
\text { MCS }\end{array}$ \\
\hline Agost & $\mathrm{V}$ & IV & IV & \\
\hline Aguilas (Faro) & II & II & II & \\
\hline Albatera & V & VI & VI & \\
\hline Albudeite & II & II & II & \\
\hline Alcantarilla & IV & III & III & \\
\hline Alcazares (Los) & $\mathrm{F}$ & & & \\
\hline Alcoy & IV & $\mathrm{V}$ & $\mathrm{V}$ & V-VI \\
\hline Aledo & II & II & II & \\
\hline Algorfa & VII & VIII & VIII & \\
\hline Alguazas & IV & IV & IV & \\
\hline Algueña & F & & & $\mathrm{V}$ \\
\hline Alicante & V-VI & & & \\
\hline Almoradi & VII & VIII & VIII & VIII \\
\hline Archena & II & III & III & \\
\hline Aspe & V & $\mathrm{V}$ & V & \\
\hline Bañeres & I & II & II & \\
\hline Beneixama & F & & & \\
\hline Benejuzar & VII & VIII & VIII & VIII \\
\hline Benferri & VI & VI & VI & \\
\hline Beniel & $\mathrm{V}-\mathrm{VI}$ & VI & VI & \\
\hline Benijofar & VI & VII & VII & \\
\hline Benimantell & III & III & III & \\
\hline Bigastro & VII & VII & & \\
\hline Bocanegra & VII & $S$ & & \\
\hline Callosa de Segura & VI & VI & VI & \\
\hline Campello & IV & IV & IV & \\
\hline Campos del Rio & $\mathrm{V}$ & $\mathrm{V}$ & V & \\
\hline Cartagena & IV & V & & V-VI \\
\hline Catral & VI & VII & VII & \\
\hline Ceuti & IV & IV & IV & \\
\hline Confrides & II & II & IV & \\
\hline Las Torres de Cotillas & IV & IV & $\mathrm{IV}(1)$ & \\
\hline Crevillente & V-VI & VI & VI & \\
\hline Daya Nueva & VI-VII & $S$ & & \\
\hline Dolores & VI & VII & VII & VIII \\
\hline Elche & VI & VI & VI & VI-VII \\
\hline Elda & III-IV & III & III & \\
\hline El Estacio (Faro) & IV & $\mathrm{V}$ & $\mathrm{V}$ & \\
\hline Formentera de Segura & VI-VII & VIII & VIII (1) & \\
\hline Fortuna & $\mathrm{V}$ & IV & IV & \\
\hline Guardamar de Segura & VI-VII & VII & VII & \\
\hline Granja de Rocamora & VI & VI & VI & \\
\hline Guadalest & IV-V & IV-V & $\mathrm{V}$ & \\
\hline Hondon de las Nieves & $\mathrm{V}$ & $\mathrm{V}$ & $\mathrm{V}$ & \\
\hline Hurchillo & $\mathrm{V}$ & $S$ & & \\
\hline Huerta (faro del cabo de la) & II & II & II & \\
\hline Jacarilla & VII & VIII & VIII & \\
\hline
\end{tabular}

Table 2 (continues on next page). 


\begin{tabular}{|c|c|c|c|c|}
\hline & $\begin{array}{l}\text { Definitive } \\
\text { EMS98 }\end{array}$ & $\begin{array}{l}\text { Report } \\
\text { MCS }\end{array}$ & $\begin{array}{c}\text { Galbis }[1932] \\
\text { MCS }\end{array}$ & $\begin{array}{c}\text { Sánchez }[1919 a] \\
\text { MCS }\end{array}$ \\
\hline Jijona & IV-V & IV & IV & \\
\hline Marquesa (La) & $\mathrm{D}$ & & & \\
\hline Mazarron & III & III & III & \\
\hline Mazarron (Faro) & III & III & & \\
\hline Montanaro (Lo) & VI & $S$ & & \\
\hline Muchamiel & IV & IV & IV & \\
\hline Mula & II & III & III & \\
\hline Murcia & III-IV & & & $(\mathrm{V}-\mathrm{VI})$ \\
\hline Novelda & IV & IV & IV & \\
\hline Onteniente & III & III & & \\
\hline Onil & II & & & \\
\hline Orcheta & II & II & & \\
\hline Orihuela & V-VI & VI-VII & II & VII \\
\hline Palos (faro del cabo de) & IV & V & $\mathrm{V}$ & \\
\hline Palma (La) & $S$ & & & \\
\hline Peceto (Lo) & VII & VIII & & \\
\hline Petrel & IV & III & III & \\
\hline Pilar de la Horadada & $\mathrm{V}$ & V-VI & VI & \\
\hline Portman (faro de) & IV & $\mathrm{V}$ & & \\
\hline Planes & III-IV & III & & \\
\hline Pliego & III & III & III & \\
\hline Puebla de Rocamora & $\mathrm{V}$ & VII & VII & \\
\hline Rafal & VII & VIII & VIII & \\
\hline Rebate & VI & $S$ & & \\
\hline Redovan & VI & VI-VII & VI-VII & \\
\hline Relleu & III & III & III & \\
\hline Ricote & III & III-IV & III-IV & \\
\hline Rojales & VI-VII & VIII & VIII & VIII \\
\hline San Javier & $\mathrm{V}$ & VI & VI & \\
\hline San Miguel de Salinas & VI & VI & VI & \\
\hline San Fulgencio & VI-VII & VII-VIII & VIII & \\
\hline San Pedro de Pinatar & VI & VI & VI & \\
\hline San Vicente & IV-V & IV & IV & \\
\hline Santa Pola (faro del cabo de) & IV & IV & IV & \\
\hline Santa Pola & IV-V & V & & \\
\hline Tabarca (isla de) & IV & IV & & \\
\hline Tercia (La) & $\mathrm{V}$ & $S$ & & \\
\hline Tibi & IV & IV & IV & \\
\hline Torremendo & VII-VIII & $S$ & VIII & VIII \\
\hline Torre Pacheco & VI & VI & VI & \\
\hline Torrevieja & V-VI & & & \\
\hline Union (La) & $\mathrm{V}$ & V & $\mathrm{V}$ & \\
\hline Villanueva del Segura & IV & IV & IV & \\
\hline Venta del Empalme & VI-VII & VIII & & \\
\hline
\end{tabular}

Table 2 (continued from previous page). Available intensity data points for the main shocks. Four different sets are given. First column shows the new evaluation from our study, in EMS98. Second column is the evaluation, in MCS scale, existing in the located manuscript report. Third column is the dataset, in MCS, given in the catalogue of Galbis [1932]. The fourth column is the dataset given by Sánchez Navarro-Neumann [1919a], also in MCS scale. 
pose form sheets and the assigned intensities and the name of the informers match those stated in the catalogue of Galbis [1932]. For these reasons, we assume it is a copy of the original report elaborated by a team of the Instituto Geográfico Nacional (IGN), composed by the engineers Barandica, Inglada and Garcia de Lomas [Galbis 1932: p. 659], which performed a field study shortly after the events. We knew about this survey, but the study itself was lost and up to present the available macroseismic information was just the assigned intensity data points on MCS scale listed in Galbis [1932]. Sparse macroseismic information on the aftershock series was also collected. Some additional information about this event was found in Garrido [2012].

\section{Macroseismic effects evaluation}

After complementing the information with those contained in contemporary newspapers and studies, we were able to reevaluate the intensity data points of these earthquakes in EMS98 scale. As the two main events occurred just 16 minutes apart and they are quite similar in size, it has been impossible to disaggregate their macroseismic effects. Thus, just a unique collection of intensity data points is available for the two main shocks. Instead, we have been able to collect distinct intensity data points for seven aftershocks. This information was unavailable up to the present and gives a new picture of the series of earthquakes. Summarizing, data for 91 sites affected by the two main shocks and a total of 44 places affected by seven aftershocks have been reevaluated. The results are presented in Tables 2 and 3 respectively. Figure 2 shows the macroseismic map for the main shocks.

Another interesting point for our analysis is the significant amount of information on ground effects collected for this event. Rock falls, liquefaction features and cracks were clearly observed at that time. Also, two observations of terrain undulation were recorded. Table 4 presents the available information on this subject graphically summarized on Figure 3. Moreover, an observation of "sea agitation" near Guardamar is accounted and DBN bulletin states that the main events were felt on board of steamer "Karimata", on Torrevieja harbor.

The fact that several witnesses of the earthquakes point to dust raising on the agricultural fields during the shaking surprised us. But this last observation losses part of its relevance when, after a study of the contemporary meteorological bulletins, we know that there was no rain in the whole region since the end of June month [Resumen 1924] and, since the beginning of the year, the region was suffering a drought.

\section{Earthquake location}

From the analysis of its macroseismic field, it is clear that these earthquakes located in or near the lower valley of the Segura River, in SE Spain. This fact is acknowledged in almost all published bulletins from Spanish or foreign stations (CRT, FBR, STR, COI, DBN) and this region is clearly stated in all of them. For this reason it is not clear how the ISS, which information sources at that time were mainly relying on the printed seismic bulletins from the different stations, misses the target and converts this event in two separate ones. The ISS [1924, pp. 125-128] groups the arrival times of the main earthquakes and aftershocks into two different sets and locate them independently. From one side, using all stations to the south of the Pyrenees, and assuming that COI readings are $3 \mathrm{~min}$ out of time, locates an event at $41.5^{\circ} \mathrm{N}, 7.0^{\circ} \mathrm{W}$ in NE Portugal (even the COI station bulletin states this is an earthquake occurred in SE Spain). From another side, just with stations to the north of the Pyrenees locates a second event, occurring four minutes later, at $44.0^{\circ} \mathrm{N}, 2.5^{\circ} \mathrm{E}$, in the $S$ of France. Only the Italian bulletin repeats this error; but as it was published after the ISS bulletin we may assume they just copied locations of foreign events from ISS. Instead, later published Spanish catalogues of Munuera [1963] and Mezcua and Martínez-Solares [1983], as well as the European catalogue of Karnik [1969], locate it properly.

We haven't any idea how this error slide on the ISS; but the fact is that it is still consigned in the present database of ISC. It is worth to point here that it is necessary to be aware of these errors (even just a few) still existing in the present ISC catalogue related to some "not so big" earthquakes when dealing with the database. In few words, ISC catalogue still contain some "fake" earthquakes as this term is understood when dealing with macroseismic events.

\subsection{Instrumental location}

Coming back to the real location itself, and trying to improve its quality, we grouped the readings contained in ISS in proper way and check as many as possible from the contemporary bulletins. We completed and corrected these readings with others we did ourselves on the available seismograms (originally, ALI and EBR bulletins, as published in Galbis [1932: pp. 303304], did not consigned $S$ waves even they are quite clear on the records). Location was performed with Hypocenter [Lienert and Havskov 1995] under SEISAN environment [Ottemöller et al. 2011]. Several trials, using all available readings, or just with P-waves, or with S-P times, etc. were performed. Our best solutions for the two main shocks are $38.14^{\circ} \mathrm{N}, 0.62^{\circ} \mathrm{W}, 0 \mathrm{~km}$ 
THE AUTUMN 1919 TORREMENDO (JACARILLA) EARTHQUAKE SERIES (SE SPAIN)

\begin{tabular}{|c|c|c|c|c|c|c|c|c|}
\hline \multirow[t]{2}{*}{ Place } & $\begin{array}{c}10 \text {-sep } \\
11: 59\end{array}$ & $\begin{array}{c}10 \text {-sep } \\
14: 22\end{array}$ & $\begin{array}{c}\text { 11-sep } \\
0: 38\end{array}$ & $\begin{array}{c}\text { 23-sep } \\
5: 15\end{array}$ & $\begin{array}{c}\text { 07-oct } \\
7: 22\end{array}$ & $\begin{array}{c}27 \text {-oct } \\
14: 44\end{array}$ & $\begin{array}{l}\text { 05-nov } \\
4: 25: 42\end{array}$ & $\begin{array}{l}\text { 09-nov } \\
8: 06: 14\end{array}$ \\
\hline & MCS & MCS & MCS & EMS98 & & & EMS98 & EMS98 \\
\hline Alicante & & & F & & & & & \\
\hline Agost & F & F & & & & & & \\
\hline Aguilas (Faro) & & & & & & III-IV & & \\
\hline Albatera & $\mathrm{F}$ & $\mathrm{F}$ & F & & & & & \\
\hline Albudeite & & & & & & & & $\mathrm{F}$ \\
\hline Alcantarilla & $\mathrm{F}$ & & & & & & & \\
\hline Alcoy & & & & & & & & $\mathrm{F}$ \\
\hline Almoradi & F & F & F & IV-V & IV & & & \\
\hline Aspe & & & $\mathrm{F}$ & & & & & \\
\hline Benejuzar & & & & IV-V & $\mathrm{V}$ & V & V & V \\
\hline Benferri & F & $\mathrm{F}$ & F & & & IV & III & IV \\
\hline Benijofar & (F) & & & F & & & & \\
\hline Bigastro & & & & IV-V & $\mathrm{F}$ & V & & \\
\hline Callosa de Segura & IV & IV & F & & & & III-IV & IV \\
\hline Cartagena & & F & F & & & & & \\
\hline Cotillas & $\mathrm{F}$ & $\mathrm{F}$ & F & & & & & \\
\hline Catral & $\mathrm{F}$ & $\mathrm{F}$ & $\mathrm{F}$ & & & & & \\
\hline Crevillente & F & F & $\mathrm{F}$ & & & & & \\
\hline Dolores & & F & & & & & $\mathrm{F}$ & \\
\hline Elx & & $\mathrm{F}$ & & & & & & \\
\hline Fortuna & & & F & & & & & \\
\hline Granja de Rocamora & $\mathrm{F}$ & $\mathrm{F}$ & & & & & & \\
\hline Hondon de las Nieves & & & F & & & & & \\
\hline Jacarilla & & & $\mathrm{F}$ & F & IV & IV-V & IV & IV \\
\hline Mazarrón & & $\mathrm{F}$ & & & & & & \\
\hline Murcia & F & $\mathrm{F}$ & $\mathrm{F}$ & & & & & \\
\hline Onteniente & $\mathrm{F}$ & & F & & & & & \\
\hline Orihuela & V & V-VI & V & III & III-IV & III-IV & III & III-IV \\
\hline Palos & & $\mathrm{F}$ & & & & & & \\
\hline Pilar de la Horadada & & & F & & & & & \\
\hline Pobla de Rocamora & F & & & & & & & \\
\hline Portman & & $\mathrm{F}$ & & & & & & \\
\hline Rafal & & & $\mathrm{F}$ & & III-IV & II-III & IV & IV \\
\hline Rebate & & & & & & & F & $\mathrm{F}$ \\
\hline Redovan & $\mathrm{F}$ & & $\mathrm{F}$ & & III & F & & $\mathrm{F}$ \\
\hline Rojales & VI & VII & V & IV & V & III & V & V \\
\hline San Miguel de Salinas & & $\mathrm{F}$ & F & & & IV-V & IV & IV \\
\hline San Felipe Neri & & & & F & & & & \\
\hline San Fulgencio & $(\mathrm{F})$ & & $?$ & & III-IV & III-IV & & \\
\hline San Pedro de Pinatar & $\mathrm{F}$ & $\mathrm{F}$ & & & & IV & & IV \\
\hline Santa Pola & & $\mathrm{F}$ & $\mathrm{F}$ & & & & & \\
\hline Tabarca & & $\mathrm{F}$ & & & & & & \\
\hline Tibi & & & $\mathrm{F}$ & & & & & \\
\hline Torremendo & & & $\mathrm{F}$ & IV-V & F & IV-V & & \\
\hline Torrepacheco & F & F & & & & & & \\
\hline
\end{tabular}

Table 3. Intensity data points for eight main aftershocks. Those in EMS98 scale were reevaluated in this article. For those in MCS scale we haven't assembled enough data to confidently reevaluate the intensity data points and we keep those intensities stated in the collected manuscript documents. F states for felt, without intensity degree assignation. 


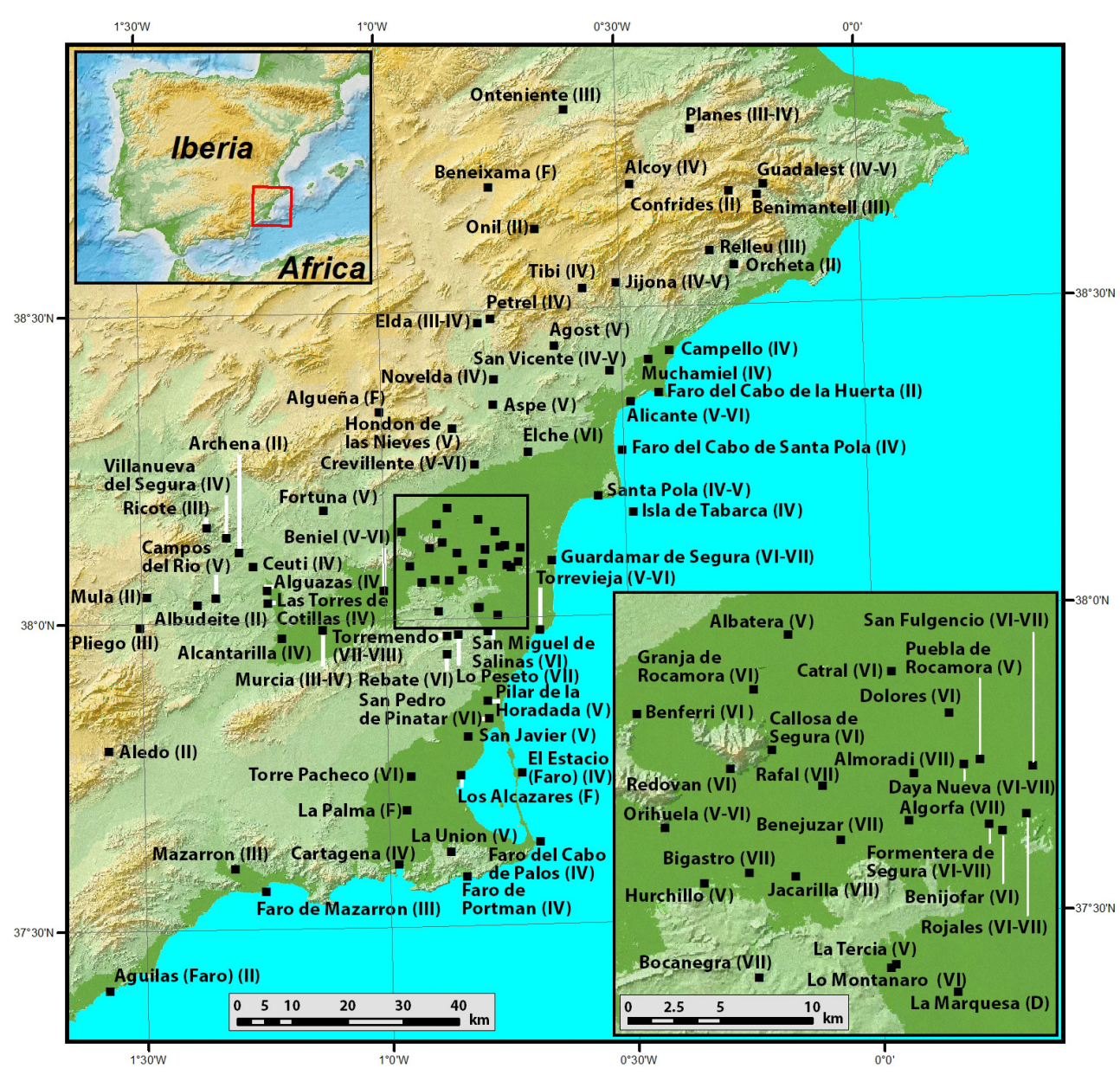

Figure 2. Macroseismic intensity map for the main events. As these events occurred just 18 minutes apart, it is impossible to disentangle their macroseismic effects and the map should be look as the joint result of both. Intensities are evaluated in EMS98.

depth $(\mathrm{rms}=5.0 \mathrm{~s})$ and $37.91^{\circ} \mathrm{N}, 0.74^{\circ} \mathrm{W}, 7.3 \mathrm{~km}$ depth $(\mathrm{rms}=4.3 \mathrm{~s})$ respectively. They are fully compatible with our macroseismic knowledge but they show large errors. Figure 4 shows the ellipse errors obtained with Hypocenter for the two main events. The mean horizontal uncertainty of the locations is larger than $50 \mathrm{~km}$. As a result, instrumental relocations, even consistent with what is known, do not allow a better constrain of the epicentral zone.

There are some reasons for the large errors found in this case. The first one, common to all events of that time, is the poor time accuracy of the station clocks. Another reason, directly related to this event, is that many Pwaves arrivals were discarded because of their really emergent character. This introduces large errors on the readings at all stations located more than $3^{\circ}$ farther away from the epicentral zone. Finally, records for most Spanish stations, specifically those located nearest to the earthquake (ALI, ALM, MAL and TOL), were obtained with Bosch-Omori and Vicentini seismographs types. The minute time marking of these instruments was, at that time, superposed on the ground motion record with an independent stylus introducing parallaxes hard to correct that translate to the bulletins.

\subsection{Macroseismic location}

The evaluated set of macroseismic data points allowed us to calculate independently an estimate for the epicenter. Macroseismic location and magnitude were determined using two different algorithms, BOXER [Gasperini et al. 1999] and Bakun and Wentworth [1997]. In both cases we used attenuation laws calculated for the Iberian Peninsula [Stucchi et al. 2010].

As stated, it is not possible to disentangle the effects of the two main shocks and just one location is obtained. The Boxer algorithm locates epicenter at $38.06 \mathrm{~N}, 0.86 \mathrm{~W}$, $\pm 6.0 \mathrm{~km}$, with magnitude $\mathrm{M}=4.9 \pm 0.2$, the Bakun and Wentworth algorithm gives $38.06 \mathrm{~N}, 0.80 \mathrm{~W}$, and $\mathrm{M}=$ $4.8 \pm 0.1$. Shallow depth is assumed in both algorithms. Boxer locates slightly to the $\mathrm{W}$ of Bakun's solution, but the results basically agree among them, also in magnitude values, and they are quite similar to the solution consigned in the Mezcua and Martinez Solares catalogue [1983] - $38.083 \mathrm{~N}, 0.833 \mathrm{~W}$ - due to Inglada [1926], or Mezcua et al. [2013] as shown in Figure 4 (left).

\section{The series of aftershocks}

As stated, the two main shocks were followed by many aftershocks; but different catalogues show dis- 


\begin{tabular}{|c|c|c|c|c|c|c|c|}
\hline Place & Ground cracks & $\begin{array}{l}\text { Water spills } \\
\text { in ditches } \\
\text { and rivers }\end{array}$ & $\begin{array}{l}\text { Water } \\
\text { changes } \\
\text { in wells }\end{array}$ & Sandspots & $\begin{array}{c}\text { Rock } \\
\text { fallings }\end{array}$ & Trees & $\begin{array}{l}\text { Crop } \\
\text { fields }\end{array}$ \\
\hline Albatera & & & Yes & & & & \\
\hline Algorfa & Near the river & Yes & & & & & \\
\hline Benejuzar & Near the river & Yes & Yes & & & $\begin{array}{l}\text { Palms } \\
\text { shake }\end{array}$ & Ondulations \\
\hline Beniel & & Waves on river & & & & & \\
\hline Benijofar & Yes & & & Yes & & & \\
\hline Bocanegra & & & & & Yes & & \\
\hline Catral & & Yes & & & & & \\
\hline Elche & & & & & Yes & & \\
\hline Formentera de Segura & Many & Yes & & Like palms & & & \\
\hline \multicolumn{8}{|l|}{ Fortuna } \\
\hline Guardamar de Segura & & & $\begin{array}{l}\text { Orchards and } \\
\text { beaches }\end{array}$ & & & & \\
\hline Granja de Rocamora & Some & & & & & $\begin{array}{l}\text { Some trees } \\
\text { fall }\end{array}$ & \\
\hline Jacarilla & Yes & Waves on river & & $\begin{array}{l}\text { On river } \\
\text { margins }\end{array}$ & & & \\
\hline Peceto (Lo) & $\begin{array}{l}\text { Many }(10-15 \mathrm{~cm} \times 15-20 \mathrm{~m}) \\
\text { NE-SW (some at right an- } \\
\text { gles). Some } 100 \mathrm{~m} .\end{array}$ & & & & & & $\begin{array}{l}\text { Ridges and } \\
\text { furrows lev- } \\
\quad \text { eled }\end{array}$ \\
\hline Rafal & & Spills & & & & & \\
\hline Rebate & Ground cracks of $10 \mathrm{~m} \mathrm{NE}$ & & & & & Trees shake & \\
\hline Rojales & $\begin{array}{l}\text { Ground cracks of } 2-5 \mathrm{~m} \\
\text { near river. NW-SE. }\end{array}$ & & & Yes & Yes & & $\begin{array}{c}\text { Ground } \\
\text { waves }\end{array}$ \\
\hline San Fulgencio & & Water spills & & & & & \\
\hline Torremendo & $\begin{array}{l}\text { One of } 100 \mathrm{~m} \times 40-50 \mathrm{~cm} \text {, } \\
1 \mathrm{~m} \text { deep. Many of } 10-15 \mathrm{~m} \\
\text { NE-SW, some at right an- } \\
\text { gles. Some on the side road. }\end{array}$ & & & & & & $\begin{array}{l}\text { Ridges and } \\
\text { furrows lev- } \\
\text { eled. Foot- } \\
\text { steps erased }\end{array}$ \\
\hline Torre Pacheco & & & Yes & & & & \\
\hline Venta del Empalme & & & & & & & $\begin{array}{l}\text { Ridges and } \\
\text { furrows } \\
\text { leveled }\end{array}$ \\
\hline
\end{tabular}

Table 4. The different kinds of the observed terrain and environmental effects and places where they were observed.

crepancies on the number, date and time of these aftershocks. We try to elaborate a new list just with the confirmed events. Seismograms of the ALI seismic station, the nearest one to the epicenter, have been fundamental to this purpose. Awfully, ALI was located inside Alicante city and large cultural noise is affecting the Vicentini records, the best suited for the recording of small aftershocks, masking the presence of some of these small events. Also, seismograms for a few days of the period under study are missing.

From our analysis of the available original records, we confirm that bulletin picks from ALI station, published in Galbis [1932], contain all events we were able to identify on them. For this reason, we also assume as true events those contained in the ALI bulletins and for which seismograms are not available anymore.

Moreover, as it is still common on earthquakes of that time, not all the confirmed aftershocks were instrumentally recorded. On the studied macroseismic documentation about the earthquake three lists of felt aftershocks, written by three independent authors living at different places in the epicentral zone 


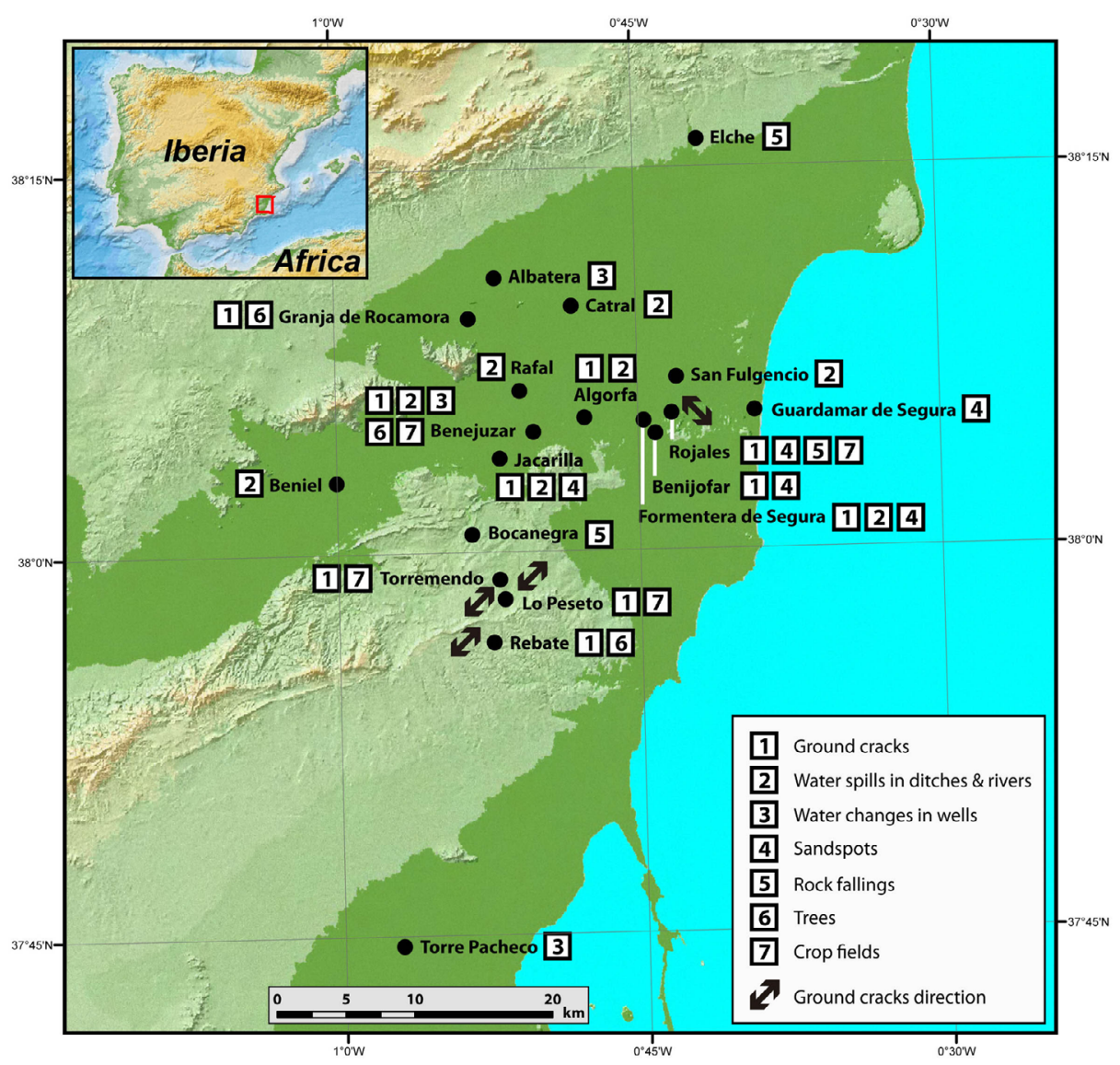

Figure 3. Observed terrain and environmental effects. As stated in Figure 2, this map shows the cumulative effects of the two main events occurred 18 minutes apart. See Table 4 for more detailed explanation.
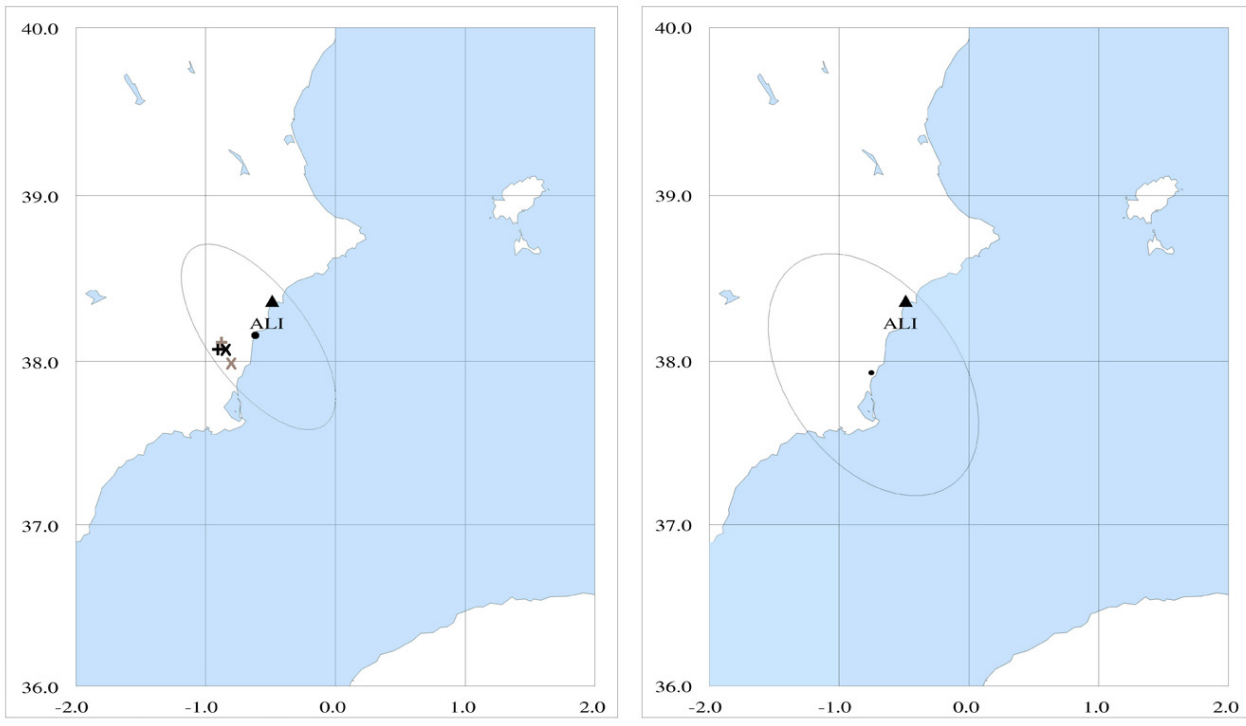

Figure 4. Instrumental location of the two main events (black dots) and error ellipses obtained with Hypocenter. Left: the 10:40 event; right: the 10:56 event. On the left figure are also shown the previous locations by Mezcua and Martínez Solares [1983] - grey cross - and Mezcua et al. [2013] - grey x -, also our location using Boxer - black cross - and Bakun and Wentworth - black x - methods.

(A. Martínez in Torremendo, G. Baches in Rojales and $\mathrm{J}$. Andreu in Orihuela), are available. Timing of the aftershocks is a problem because, even Spanish administration adopted GMT already in 1901, by 1919 we found that the countryside was still using the local solar time with low precision (clocks and watches were not com- mon among the peasants). But, for us, the list of felt aftershocks at Rojales, compiled by G. Baches, and those felt at Orihuela, compiled by J. Andreu, are of great interest because, even showing differences in absolute timing, they show coherency among them and with the records of the ALI station. For this reason we also as- 


\begin{tabular}{|c|c|c|c|}
\hline Day & Time & Inst a/o Mac & Felt at \\
\hline 1919:09:10 & $10: 40: 46$ & $\mathrm{I} \& \mathrm{M}$ & See Table 2 \\
\hline 1919:09:10 & $10: 56: 57$ & $\mathrm{I} \& \mathrm{M}$ & See Table 2 \\
\hline 1919:09:10 & $10: 57: 30$ & I & Recorded at ALI \\
\hline 1919:09:10 & $11: 07: 36$ & $I \& M$ & Orihuela \\
\hline 1919:09:10 & 11:59:14 & $\mathrm{I} \& \mathrm{M}$ & See Table 3 \\
\hline 1919:09:10 & $14: 22: 42$ & $I \& M$ & See Table 3 \\
\hline 1919:09:10 & $15: 49: 56$ & $\mathrm{I} \& \mathrm{M}$ & Orihuela, Rojales \\
\hline 1919:09:10 & $15: 51: 58$ & I & Recorded at ALI \\
\hline 1919:09:11 & $0: 38: 34$ & $\mathrm{I} \& \mathrm{M}$ & See Table 3 \\
\hline 1919:09:11 & $5: 20: 39$ & I $\& \mathrm{M}$ & Orihuela \\
\hline 1919:09:11 & 14:25:-- & M & Orihuela, Rojales \\
\hline 1919:09:11 & $22: 20:--$ & M & Orihuela, Rojales \\
\hline 1919:09:15 & $6: 37: 03$ & I & Doubtful \\
\hline 1919:09:22 & $8: 36: 29$ & I & Doubtful \\
\hline 1919:09:22 & $10: 38: 21$ & I & Doubtful \\
\hline 1919:09:22 & $10: 48: 54$ & I & Doubtful \\
\hline 1919:09:22 & $18: 09: 25$ & I & Doubtful \\
\hline 1919:09:23 & 05:15:-- & $\mathrm{M}$ & See Table 3 \\
\hline 1919:09:25 & 20:30:-- & M & Torremendo \\
\hline 1919:10:07 & 07:17:-- & M & Rojales, Torremendo \\
\hline 1919:10:09 & 8:09:02 & I \& M & Rojales, Callosa \\
\hline 1919:10:09 & $9: 01: 29$ & I & Recorded at ALI \\
\hline 1919:10:27 & $13: 31: 21$ & $\mathrm{I} \& \mathrm{M}$ & Orihuela, Torremendo \\
\hline 1919:10:27 & $14: 44: 14$ & I \& M & See Table 3 \\
\hline 1919:11:03 & $17: 37: 11$ & I & Doubtful \\
\hline 1919:11:05 & $4: 25: 42$ & $\mathrm{I} \& \mathrm{M}$ & See Table 3 \\
\hline 1919:11:09 & $8: 06: 14$ & I \& M & See Table 3 \\
\hline 1919:11:20 & $14: 31: 13$ & I & Doubtful \\
\hline
\end{tabular}

Table 5. Series of confirmed aftershocks. Third column states if the aftershock was instrumentally recorded (I), just felt (M) of both. Fourth column states places where it was felt or redirects to Table 3.

sume the events recorded in these lists as true.

Table 5 shows the assembled list of aftershocks. They extend at least up to November. The timing of the events in the new list can be considered accurate up to the minute for those recorded instrumentally (among them, a new one in the coda of the second main even clearly identified in the seismograms of ALI station) and up to 10 minutes for those just felt.

We see that some events are recorded just instrumentally (ex. the four aftershocks on 22 September). Instead, aftershocks widely felt (23 September or 7 October) were not recorded. As the last two occurred before or around daybreak, it is quite probable people at rest were prone to feel them.

\section{Magnitudes and focal mechanism}

We are interested in the focal mechanism of these earthquakes. For this reason seismograms were digitized and inverted following the procedures described in previous studies of other Iberian earthquakes [Stich et al. 2003, Stich et al. 2005, Batlló et al. 2008, Batlló et al. 2010]. A total of 44 files, corresponding to 44 recorded single components from the different events ( 32 for the two main events and 12 for the aftershocks) have been processed. Awfully, in this case the energy contained in the digitized seismograms is too small to allow for any stable result from the inversion of the waveforms. For this reason, we decided to obtain just a direct estimate of the scalar seismic moment and $\mathrm{Mw}$ magnitude using the 

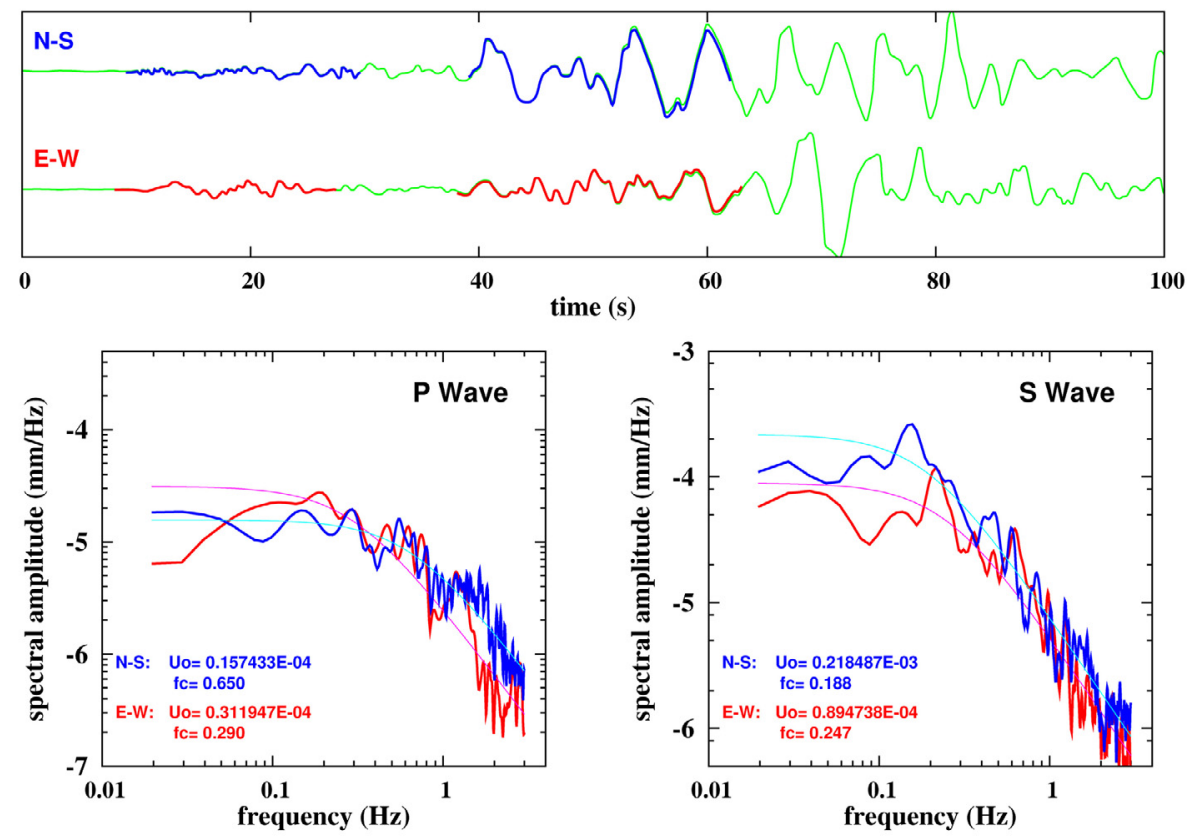

Figure 5. Digitized seismograms of the first main shock, occurred at 10:40, as recorded on the Bifilar pendulums at CRT seismic station and seismic moment calculation for $\mathrm{P}$ and $\mathrm{S}$ waves. At the top, the dark blue and red parts of the seismogram show the selected fragments of $\mathrm{P}$ and $S$ waves for spectra calculation on the N-S and E-W digitized components respectively. At the bottom the Brune' model fitting of each spectrum is shown.

methodology described in Dineva et al. [2002]. Figure 5 shows an example of a digitized seismogram from station CRT and the calculated P and S-wave spectra.

As S-waves are clearer on the records than P-waves, we used them to calculate the size of the main events. Both are quite similar in magnitude. We obtained seismic moments of $\mathrm{Mo}=2.1 \times 10^{17} \mathrm{Nm}$ and $1.3 \times 10^{17}$ $\mathrm{Nm}$ and $\mathrm{Mw}=5.48 \pm 0.21$ and $\mathrm{Mw}=5.28 \pm 0.26$ for the 10:40 and 10:56 events using 5 (CRT, TOL, PAR, STR, DBN) and 6 (CRT, TOL, EBR, PAR, STR, DBN) stations respectively. ALI records were not used because, as station locates less than $50 \mathrm{~km}$ far away from

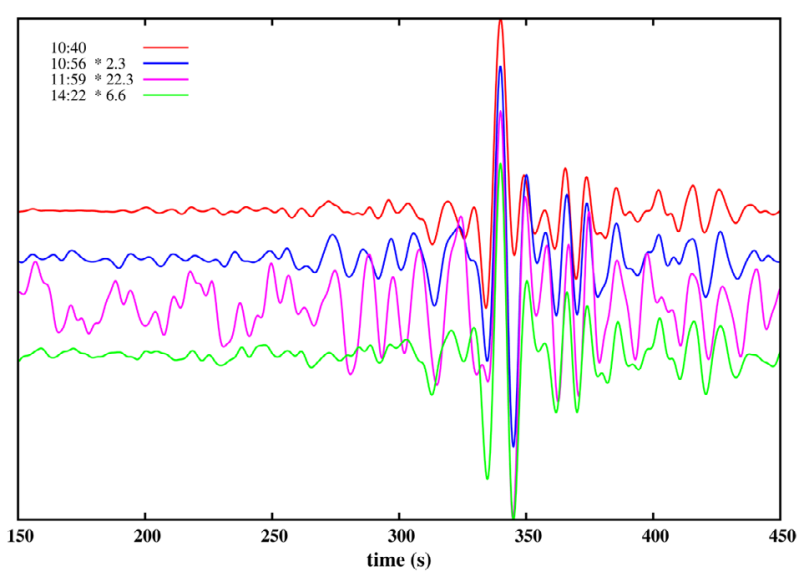

Figure 6. Digitized records of the surface wave trains of the two main events (10:40 and 10:56) and two aftershocks (11:59 and 14:22) recorded on the vertical component of the Galitzin instrument at PAR station. Multiplying the amplitude of each record times the factor shown in the figure to equalize the maximum peak, it is easy to see the similarity of surface wave trains for the four records. the epicenter, the records, obtained with the BoschOmori instruments, show problems related to the mechanical recording system.

We try also to calculate the magnitude of some aftershocks. As already explained, records of ALI do not seem suitable to use in this case. But the records of PAR vertical and DBN horizontal Galitzin seismographs for 10 September 1919 recorded nicely the surface waves of the two main events and of some aftershocks occurred on the first day. Assuming same location and focal mechanism for all of them, the differences in surface waves amplitudes should be related just to the different size of the events. Scaling the records with respect to the first main event (as shown in Figure 6), confirm the similarity of recorded waves. Using a window of $60 \mathrm{~s}$ around the maximum recorded amplitude and applying a L2 norm to calculate relative amplitudes we obtained magnitudes of $\mathrm{Mw} 4.0$ for the event at 11:59 and Mw 4.4 for the 14:22 aftershock, both occurred on 10 September.

\section{Discussion and conclusions}

We reanalyzed the 1919 SE Spain events from original instrumental and macroseismic records. First concern is about the nearest place to the earthquake. Up to now these events where known as "Jacarilla earthquakes". Our macroseismic analysis points to maximum observed effects near the small village of Torremendo, $7 \mathrm{~km}$ to the $S$ of Jacarilla, a little bit out of the Segura river valley and in a less populated area. Also, all calculated locations, instrumental and macroseismic, points to 


\begin{tabular}{ccccccc} 
Epi. & Dataset & Method & Attenuation & Lat. & Lon. & Mag. \\
\hline 1 & EMS98 & B \& W & NA4 Iberia & 38.06 & -0.80 & $4.8 \pm 0.1$ \\
2 & Galbis & B \& W & NA4 Iberia & 38.07 & -0.77 & $4.8 \pm 0.1$ \\
3 & EMS98 & B \& W & Mezcua et al. & 38.06 & -0.81 & $5.0 \pm 0.1$ \\
4 & Galbis & B \& W & Mezcua et al. & 38.07 & -0.77 & $5.1 \pm 0.1$ \\
5 & EMS98 & Boxer & NA4 Iberia & 38.06 & -0.86 & $4.8 \pm 0.1$ \\
6 & Galbis & Boxer & NA4 Italia & 38.09 & -0.80 & $5.3 \pm 0.2$ \\
7 & EMS98 & Boxer & NA4 Italia & 38.06 & -0.86 & $4.9 \pm 0.2$ \\
8 & Galbis & Boxer & NA4 Iberia & 38.09 & -0.80 & $4.9 \pm 0.2$ \\
\hline
\end{tabular}

Table 6. Macroseismic location and magnitude of the main shocks using different intensity dataset and macroseismic attenuation equations. Figure 7 shows the different locations for the different cases. See discussion for details.

an epicenter slightly to the SE of the actually consigned place. These results are also in agreement with the recent results of Mezcua et al. [2013]. For this reason, and following the policy of IGN on naming the earthquakes from the nearest town to their epicenter, these events should be better known as the "Torremendo earthquakes".

We assigned a maximum intensity degree of VIIVIII EMS98 for the main events. Intensity degree assignation is not an analytical operation and depends on many factors (the evaluator among them) as has been discussed by Musson et al. [2010]. In our case, we can also agree with a maximum intensity about VIII. The field undulations seen during the earthquakes may point in this direction as ESI 2007 [Michetti et al. 2007] scale associates them with that degree. Anyway, as the population density in the epicentral area was not high, the statistical assignation of an intensity degree shows less confident.

About the size of the main events, the magnitude determinations from instrumental records confirm them as the largest earthquakes occurred in the Eastern Betic Cordillera in the 20th-21st centuries $(\mathrm{Mw}=$ $5.5 \pm 0.2$ and $5.3 \pm 0.3$ respectively). Magnitude determination with macroseismic methods cannot separate, in this case, the two main events and, more important, gives a smaller size $(M=4.9 \pm 0.2)$. Instead Mezcua et al. [2013] obtained $M=5.2 \pm 0.3$ with different attenuation law and 59 intensity data points. The differences between instrumental and macroseismic calculations are large and we investigated possible causes.

First, we tested the possible changes in magnitude when using different sets of macroseismic data points and different macroseismic attenuation laws. We compared the results obtained when, instead of our new macroseismic database on EMS98 values, we use the old dataset extracted from Galbis [1932], with just 65 intensity points in MCS scale. No conversion was applied to these intensity degrees and they were used as presented in column four of Table 2 . Also, to test dependence with different attenuations and location methods, we used, for Bakun and Wentworth, the previous datasets with the Iberian attenuation laws used by Stucchi et al. [2010] and Mezcua et al. [2004, 2013]. We also tested the same datasets with BOXER and the Italian and Iberian attenuations [Stucchi et al. 2010]. Italian attenuation is used because it is given as "default" on the downloaded pack and it has been widely used in different regions when better information is not available. Table 6 summarizes the obtained results and Figure 7 shows the epicentral locations obtained for each case. As expected, epicentral location depends mainly on the used dataset and magnitude depends mainly on the attenuation law adopted. All macroseismic locations fall into an area of $9 \mathrm{~km}$ times $4 \mathrm{~km}$, confirming the adopted location. For Bakun and Wentworth method, magnitude is $0.2 / 0.3$ units larger when using the Mezcua et al. [2004], more attenuating law. Using the Boxer algorithm, magnitude shows 0.4 units larger

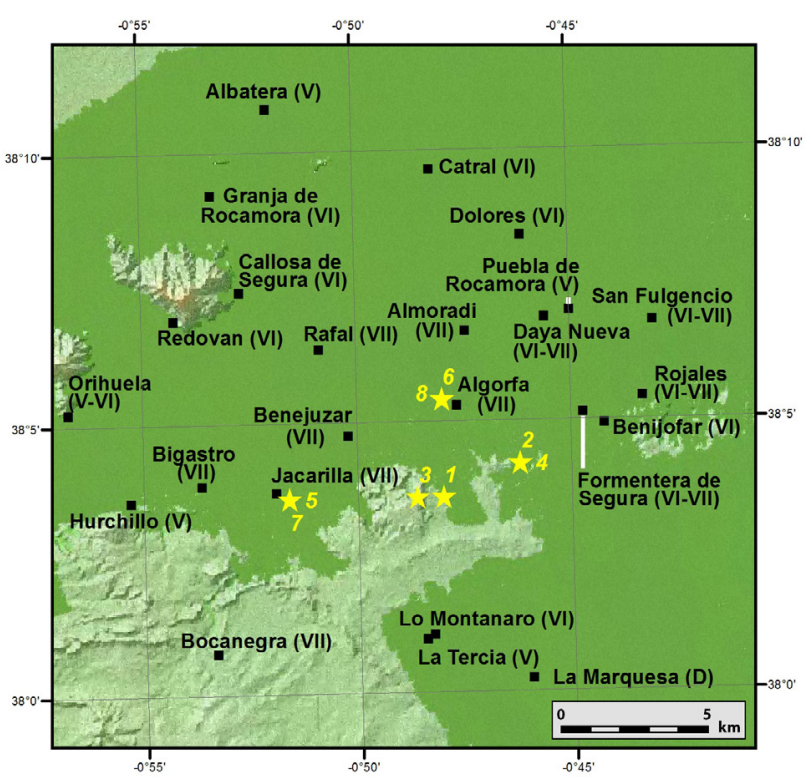

Figure 7. Macroseismic location (starts) of the main shocks using different intensity dataset and macroseismic attenuation equations as consigned in Table 6. Numbers as stated in the first column of the table. See discussion for details. 
(and near the instrumentally calculated one) when using the more attenuating Italian parameters and Galbis [1932] dataset.

To complete our test, we calculate the magnitude from the relation between $M$ and Imax available from the Boxer algorithm. They are $M=2.080+0.465 I \max$ and $M=0.937+0.561$ Imax for the Iberian and Italian attenuations respectively. Considering an Imax value of VII-VIII we obtain $M=5.6$ and $M=5.2$ respectively, with $\sigma=0.4$. In both cases we see as the M-Imax relations give larger values than using datasets.

Summarizing, using different datasets of intensity points we obtain similar results, with magnitudes in the order of half degree lower than the instrumental ones. Instead, Imax-M relations used basically agree with these instrumental results. We haven't any explanation for this fact. Maybe the local attenuation is quite different (much stronger) than assumed, or corrections for intensity due to local geology should be applied; but we haven't either any information about such phenomena in the region.

About the focal mechanism, it has been said that inversion of waveforms cannot resolve the problem. Also, it is not possible to use polarities due to the emergent character and bad azimuth coverage of the available seismograms. Instead, some insight can be acquainted from ground cracks. We recover information about ground cracks produced at ten different places (Table 4). Most of them grouped in places near the river Segura and the information (scarce) is that they were parallel to the river banks, as expected. Just at Rojales, cracks in NW-SE direction, almost perpendicular to the river, were observed. But, due to the high sinuosity of the Segura River and its distance to the epicenter this data is not significant. Instead, we collect data from three places in hilly (and drier) terrain in the epicentral area (Torremendo, Rebate and Lo Peceto). On the three places the main cracks are trending mainly in NE-SW direction with smaller ones at right angles (Figure 3 and Table 4). The trend of the main cracks is the same of the anticlinal fold axes conforming this region and the cracks lie almost at the top of the main one, the Torremendo anticline [Alfaro et al. 2002]. Such pattern is compatible with a thrust mechanism at the Bajo Segura blind fault; and also with our knowledge about the regional stress state and neotectonics and with available focal mechanism for recent smaller earthquakes [Stich et al. 2010].

We improved the macroseismic information about the main shocks and the series of aftershocks. Now, the character of the series of felt aftershocks is much better known. We revised and completed the macroseismic field of the two main shocks. Also, 16 felt aftershock and 10 events just instrumentally detected were confirmed.
The whole series lasted for a period of almost 10 weeks. The number and size of the series of felt aftershocks is quite similar to those of recent and well studied events in the region, pointing to its completeness (this is, we assume our present record keep memory of all felt aftershocks). Also, looking at the maximum intensity of the widely felt, but instrumentally unrecorded aftershocks, and from the Imax-Mw relations already used, we deduce that the instrumental threshold detection for these earthquakes at that time should be slightly less than magnitude $M w=4$. This is an important result because it can be extrapolated, at least, to the whole SE of the Iberian Peninsula up to 1925, when seismographs at the nearest stations (ALI and ALM) were updated, and this result is giving a threshold for the completeness of the regional instrumental seismicity record.

Summarizing, we reviewed and studied the 1919 Torremendo earthquake series from its original instrumental and macroseismic records. We confirm them as the largest earthquakes occurred in that region since instrumental records are available, with magnitude around $M w=5.5$ for the main shock and epicenter to the $S$ of the lower Segura valley. Observed environmental effects are compatible with a possible thrust mechanism with pressure axis in NW-SE direction. The study of the aftershock series gives important clues for the knowledge of earthquake detectability in SE Spain in the first quarter of the 20th century.

Acknowledgements. We thank Marina López Muga from Toledo Observatory and Geneviève Patau, from Geoscope, for their help to locate and reproduce seismograms from TOL and PAR stations respectively. Some seismograms and bulletins were obtained from EuroSeismos. J. F. Valero helped us drawing some figures. This research was partly funded through projects PTDC/CTEGIX/122262/2010 from Portuguese FCT and CGL2012-31472 from Spanish DGI/MEyC.

\section{References}

Alfaro, P., A. Estévez, M. Moretti and J.M. Soria (1999). Structures sédimentaires de déformation interprétées comme séismites dans le Quaternaire du bassin du Bas Segura (Cordillère Bétique orientale), Comptes Rendues Acad. Sci. Paris (II), 328, 17-22.

Alfaro, P., J. Delgado, A. Estévez and C. López-Casado (2001). Paleoliquefaction in the Bajo Segura basin (eastern Betic Cordillera), Acta Geol. Hisp., 36 (3-4), 233-244.

Alfaro, P., J.M. Andreu, J. Delgado, A. Estévez, J.M. Soria and T. Teixidó (2002). Quaternary deformation of the Bajo Segura blind fault (eastern Betic Cordillera) revealed by high-resolution reflection profiling, Geological Magazine, 139 (3), 331-341; doi:10.1017/S0016756802006568.

Alfaro, P., R. Bartolomé, M.J. Borque, A. Estévez, J. Gar- 
cía-Mayordomo, F.J. García-Tortosa, A.J. Gil, E. Gràcia, C. Lo Iacono and H. Perea (2012). The Bajo Segura Fault Zone: Active blind thrusting in the Eastern Betic Cordillera (SE Spain), Journal of Iberian Geology, 38 (1), 271-284.

Bakun, W.H., and C.M. Wentworth (1997). Estimating earthquake location and magnitude from seismic intensity data, B. Seismol. Soc. Am., 87, 1502-1521.

Batlló, J., D. Stich, B. Palombo, R. Macià and J. Morales (2008). The $1951 \mathrm{Mw} 5.2$ and 5.3 Jaén, Southern Spain, Earthquake Doublet Revisited, B. Seismol. Soc. Am., 98, 1535-1545.

Batlló, J., D. Stich, R. Macià and J. Morales (2010). The 5th July 1930 earthquake at Montilla (S Spain). Seismic Moment Tensor, Seismol. Res. Lett., 81, 724731.

Benito, B., B. Capote, P. Murphy, J.M. Gaspar-Escribano, J.M. Martínez-Díaz, M. Tsige, D. Stich, J. García-Mayordomo, M.J. García-Rodríguez, M.E. Jiménez-Peña, J.M. Insua-Arévalo, J.A. ÁlvarezGómez and C. Canora (2007). An Overview of the Damaging and Low Magnitude Mw 4.8 La Paca Earthquake on 29 January 2005: Context, Seismotectonics, and Seismic Risk Implications for Southeast Spain, B. Seismol. Soc. Am., 97, 671-690.

Bousquet, J.C. (1979). Quaternary strike-slip faults in Southeastern Spain, Tectonophysics, 52, 277-286; doi:10.1016/0040-1951(79)90232-4.

Bretón, M., and M. Espinar (1996). Fenómenos sísmicos que afectaron a las tierras andaluzas en los siglos IX al XII según las crónicas musulmanas, In: Homenaje en honor al profesor Fernando de Miguel Martínez, Univ. de Granada, Granada, 47-76.

Buforn, E., B. Benito, C. Sanz de Galdeano, C. del Fresno, D. Muñoz and I. Rodriguez (2005). Study of the Damaging Earthquakes of 1911, 1999, and 2002 in the Murcia, Southeastern Spain, Region: Seismotectonic and Seismic-Risk Implications, B. Seismol. Soc. Am., 95, 549-567.

Datos sísmicos (1919). Datos sísmicos de España: 3er trimestre 1919, Revista Ibérica, XII, no. 300, 271.

Datos sísmicos (1920). Datos sísmicos de España: 40 trimestre 1919, Revista Ibérica, XIII, no. 314, 95.

De Larouzière, F.D., J. Bolze, P. Bordet, J. Hernández, C. Montenat and P. Ott d'Estevou (1988). The Betic segment of the lithosperic Trans-Alboran shear zone during the Late Miocene, Tectonophysics, 152, 41-52.

Dineva, S., J. Batlló, D. Mihailov and T. van Eek (2002). Source parameters of four strong earthquakes in Bulgaria and Portugal at the beginning of the 20th century, J. Seismol., 6, 99-123.

Galbis, J. (1932). Catálogo sísmico de la zona compren- dida entre los meridianos $5^{\circ} \mathrm{E}$ y $20^{\circ} \mathrm{W}$ y paralelos $45^{\circ}$ y $25^{\circ} \mathrm{N}$, Tomo I. Inst. Geográfico y Catastral, Madrid, 807 pp.; http: / /www.ign.es/ign/ resources/ sismologia/ publicaciones / GalbisTomo1.pdf.

Garrido, L. (2012). Terremoto de Jacarilla de 10 de Septiembre de 1919 y su serie de réplicas, Trabajo académico dirigido, Universidad Complutense de Madrid, 30 pp.

Gaspar-Escribano, J. M., and B. Benito (2007). Ground Motion Characterization of Low-to-Moderate Seismicity Zones and Implications for Seismic Design: Lessons from Recent, $\mathrm{M}_{\mathrm{w}} \sim 4.8$, Damaging Earthquakes in SE Spain, B. Seismol. Soc. Am., 97, 531-544.

Gasperini, P., F. Bernardini, G. Valensise and E. Boschi (1999). Defining seismogenic sources from historical earthquake felt reports, B. Seismol. Soc. Am., 89, 94-110.

Inglada, V. (1926). El sismo del bajo Segura de 10 de septiembre de 1919. Cálculo de las coordenadas del foco basado en la hora inicial de los sismogramas registrados en varias estaciones próximas, Bol. Inst. Geol. Minero, 48, 35-48.

Inglada, V. (1927). Estudio de sismos españoles. El terremoto del bajo Segura de 10 de septiembre de 1919. Cálculo de su profundidad hipocentral y de la hora inicial de sus sacudidas en el foco y en el epicentro, Imprenta Clásica Española, Madrid, 72 pp.

ISS (1924). The International Seismological Summary for 1919 July, August, September, vol. 2, no. 3, 125128.

Karnik, V. (1969). Seismicity of the European area, vol. 1, D. Reidel Publishing Co., Dordrecht, Holland, 364 pp.

Kindelán, V., and J. Gorostizaga (1920). Sobre los terremotos ocurridos en las provincias de Alicante y Murcia en 1919, Boletín del Instituto Geológico de España, 42, 247-277.

Larramendi, J.A. (1829). Memoria y relación circunstanciada de los estragos que la terrible catástrofe de los terremotos de 21 de marzo y siguientes, principalmente, el del Sábado Santo 18 de abril hasta el presente día, han causado en Torrevieja y demás pueblos de la gobernación de Orihuela y sus inmediaciones, en la ciudad de Murcia y algunos pueblos de la provincia de este nombre, Imprenta Real, Madrid, 24 pp.; http: / /www.ign.es/ign/resour ces/sismologia/publicaciones/LarramendiTorrevie ja1829.pdf.

Lienert, B.R.E., and J. Havskov (1995). A computer program for locating earthquakes both locally and globally, Seismol. Res. Lett., 66, 26-36.

Martínez Solares, J.M., J.V. Cantavella Nadal, L. Cabañas Rodriguez and J.F. Valero Zornosa (2012). El terre- 
moto de Lorca de 11 de mayo de 2011 y la sismicidad de la región, Física de la Tierra, 24, 17-40.

Mezcua, J., and J.M. Martínez Solares (1983). Sismicidad del área Ibero-Mogrebí, Presidencia del Gobierno IGN, Sección de sismología, Publicación 203, Madrid; http:/ / www.ign.es/ign/resources/sismolo gia/publicaciones/SismicidaddelArealberoMogrebi. pdf.

Mezcua, J., M. Herraiz and E. Buforn (1984). Study of the 6 June 1977 Lorca (Spain) earthquake and its aftershock sequence, B. Seismol. Soc. Am., 74, 167-179.

Mezcua, J., J. Rueda and R.M. García Blanco (2004). Reevaluation of historic earthquakes in Spain, Seismol. Res. Lett., 75, 75-81.

Mezcua, J., J. Rueda and R.M. García Blanco (2013). Iberian Peninsula Historical Seismicity Revisited: An Intensity Data Bank, Seismol. Res. Lett., 84, 9-18.

Michetti, A.M., E. Esposito, L. Guerrieri, S. Porfido, L. Serva, R. Tatevossian, E. Vittori, F. Audemard, T. Azuma, J. Clague, V. Comerci, A. Gurpinar A., J. Mc Calpin, B. Mohammadioun, N.A. Mörner, Y. Ota and E. Roghozin (2007). Intensity Scale ESI 2007, In: L. Guerrieri and E. Vittori (eds.), Mem. Descr. Carta Geol. d'Italia., vol. 74, Servizio Geologico d'Italia Dipartimento Difesa del Suolo, APAT, Rome, Italy.

Morales, J., J.V. Cantavella, F.L. Mancilla, L. Lozano, D. Stich, E. Herraiz, J.B. Martin, J.A. López-Comino and J.M. Martinez-Solares (2014). The 2011 Lorca seismic series: Temporal evolution, faulting parameters and hypocentral relocation, B. Earthq. Eng., 12, 1871-1888; doi:10.1007/s10518-013-9476-x.

Munuera, J.M. (1963). A study of seismicity on the Península Ibérica area. Technical note n. 1 «Seismic Data», Instituto Geográfico y Catastral, Madrid, 93 pp.

Musson, R.W., G. Grünthal and M. Stucchi (2010). The comparison of macroseismic intensity scales, J. Seismol., 14, 413-428.

Ottemöller, L., P. Voss and J. Havskov (2011). Seisan Earthquake Analysis Software, University of Bergen, $359 \mathrm{pp}$.

Resumen (1924). Resumen de las observaciones efectuadas en las estaciones del Servicio Meteorológico Español durante el año 1919 ordenado y publicado por la Oficina Central Meteorológica, Dirección General del Instituto Geográfico, Madrid, 610 pp.

Rey Pastor, A. (1943). La comarca sísmica del Bajo Segura. Instituto Geográfico y Catastral, Servicio de Sismología, Instituto Geográfico y Catastral, Madrid; http://www.ign.es/ign/resources/sismologia/pub licaciones/ComarcaBajoSegura.pdf.

Rey Pastor, A. (1949). La comarca sísmica de Caravaca y el sismo de 23 de junio de 1948, Instituto Geografico y Catastral, Madrid; http:/ / www.ign.es/ign/
resources/sismologia/publicaciones/ComarcaCar avaca.pdf.

Rueda, J., D. Dreger, R.M. García Blanco and J. Mezcua (2014). Directivity Detection and Source Properties of the 11 May $2011 \mathrm{Mw} 5.2$ Lorca, Spain, Earthquake, B. Seismol. Soc. Am., 104, 1735-1749; doi:10.1785/ 0120130143.

Sánchez Navarro-Neumann, M. (1919a). Los temblores alicantinos de septiembre de 1919, Rev. Ibérica, 12 (301), 284.

Sánchez Navarro-Neumann, M. (1919b). Los terremotos sentidos en las provincias de Alicante y Murcia en septiembre de 1919, Rev. Soc. Astr. de España y América, 69, 85-88.

Silva, P.G., J.L. Goy, L. Somoza, C. Zazo and T. Bardají (1993). Landscape response to strike-slip faulting linked to collisional settings: Quaternary tectonics and basin formation in the Eastern Betics, Southeast Spain, Tectonophysics, 224, 289-303; doi:10.1016/00 40- 1951(93)90034-H.

Stich, D., J. Batlló, J. Morales, R. Macià and S. Dineva (2003). Source parameters of the $1910 \mathrm{Mw}=6.1$ Adra earthquake (southern Spain), Geophys. J. Int., 155, 539-546.

Stich, D., J. Batlló, R. Macià, P. Teves-Costa and J. Morales (2005). Moment tensor inversion with single-component historical seismograms: The 1909 Benavente (Portugal) and Lambesc (France) earthquakes, Geophys. J. Int., 162, 850-858.

Stich, D., R. Martín and J. Morales (2010). Moment tensor inversion for Iberia-Maghreb earthquakes 20052008, Tectonophysics, 48, 390-398.

Stucchi, M., A. Rovida, A.A. Gómez Capera, R. Musson, Ch. Papaioannou and J. Batlló (2010). NA4 European earthquake catalogue 1000-1963, M > 5.8, deliverable D10. NERIES, distributed archive of historical earthquake data (NA4), EC project number 026130, internal report; http:/ / emidius.mi.ingv.it/ neries_NA4/ deliverables.php.

Taboada, A., J.C. Bousquet and H. Philip (1993). Coseismic elastic models of folds above blind thrusts in the Betic Cordilleras (Spain) and evaluation of seismic hazard, Tectonophysics, 220, 223-241.

Corresponding author: Josep Batlló, Institut Cartogràicic i Geològic de Catalunya, Barcelona, Spain; email: josep.batllo@icgc.cat.

(C) 2015 by the Istituto Nazionale di Geofisica e Vulcanologia. All rights reserved. 